I shall return it to you all." Perhaps the best parallel is found in the letter of Biridiya of Megiddo (near Taanach) to the Pharaoh: $\bar{u}$ zurata laqī-mi kaspē ipterešu ina qātišu / ba- $\mathrm{de}_{4}-\mathrm{u},{ }^{26}$ " And Zurata received his ransom (bribe) price in his hand / in his hands." ${ }_{27}$

The failure of the docket to record the exact amount of the payment is surprising. However, the omission is understandable if the payment were in fact a bribe agreed upon by the principals, or if the payment were a predetermined sum, a fine, levy, or even a temple impost.

\title{
INSTANCES OF MOBILITY AMONG MARI ARTISANS
}

\section{JACK M. SASSON}

It should require no more than a hurried glance through the thirteen volumes of the Archives royales de Mari $^{1}$ to render it quite evident that Mari society was indeed an active one. As a city strategically located on the Euphrates, Mari played an important role in the distribution of goods among the ancient powers. These included the CyproMinoan west, shipper of the elegant pot and the rough copper; the Syro-Anatolian north, exporter of woods, stones, minerals, and some agricultural products; the Mesopotamian south, manufacturer of finished commodities; and the Elamite east, distributer of tin. For this reason, it surprises us little to discover that Mari's community had achieved a significant division of its labor force.

This paper will focus on a class of workers possessed of a certain skill which, as a rule, was obtained after a period of apprenticeship. Further, our attention will be directed to that portion of this class which seems to have, willingly or otherwise, shuttled from one city, one region, or even one country to another. The positions held by these ambulating artisans will vary enormously, ranging from those of Salomes, who performed with seven veils (ARMT XIII: 22: 41), to those of diviners. Except for the purpose of presenting what seems to be a curious-but perhaps incidental-phenomenon, there will be no attempt at differentiating between the Samsi-Adad and Zimri-Lim periods. Messengers, army personnel, or merchants whose professions naturally required extensive travelling will not be considered.

It is possible to arrange the documents at our disposal in three categories. The first deals with single individuals whose talents were sought involves groups of workers, usually not as skilled as the members of the within the confines of Mari and its immediate dependencies. The second

\footnotetext{
${ }^{28}$ We are to read the gloss /badêw/ b bayadêhū, "into his hands." One may also read "from his hands," in spite of Akk. ina qatišu. bd is not infrequently used in this sense at Ugarit. E.g., see $P R U$ V, 59:18, 21 "take (lqh) from the hand of PN." South Canaanite ladêw may also have been ambiguous.

${ }^{27} T A$ 245, 33-35.

${ }^{1}(A)$ rchives $(R)$ oyales de $(M)$ ari, volumes I-IX, XI-XIII, XV, Paris, 1950-1964. As a matter of convenience, see ARM XV, 318, sub MÉTIERS.
} 
first division, whose corvée duties demanded their presence at the capital. The third and last category comprises instances in which Mari citizens were recorded as employed by foreign dominions. The opposite, alien artisans within Mari spheres of influence, fall into this final class.

One reason for the transfer of artisans within the territories of a kingdom is connected with the political status of a district. It seems that a region designated as pattum was not permitted to remain for long with certain posts vacant. Thus ARM II: 15: 5-29, a letter from Išme-Dagan to his brother, reads:

As to Naram-Sim, the diviner, concerning whom you wrote to me, the king [Šamsi-Adad] has assigned him to the district of situllum. That district, you know, is a pattum. I have now written to the king: 'Since Narām-Sin left YasmahAdad, Yasmah-Adad has written the following to me: 'Ibāl-pi-El is the diviner who is (now) with my lord [Šmsi-Adad]'. In addition to Narām-Sin, there is no diviner who is at my disposal. Let the king send a diviner . . . The city of Situllum is a pattum and there is no pattum without a diviner. The king has already assigned a diviner for this district. ${ }^{2}$

That this concept lasted beyond Assyrian rule may be inferred from ARM XIII: 147: 27-33, a letter which was probably addressed to ZimriLim. In it a ruler of Talhayum, Yawi-Ilā, writes.

It is in a pattum city for my lord that I dwell. The physician died on 'Lamentation for the Dead ( $q i$-ir-bu-ti BA.TIL) day. Let my lord not restrain a physician from establishing himself at the 'house' (palace?) here in your city. Let him heal your servants, the citizens of Talhayum.

Much more common, however, were instances in which the artisan's round of duty involved him with the king's five palaces, located at Mari, Terqa, Sagarātim, Dūr-Yahudun-Lim, and Qattunan (VII: 277: v: 2-7; 190: 4-6, 8, 22-3). Collectively, these were known as the 'Palaces on the bank of the Euphrates (ARM V: 27: 6-7).$^{3}$ During the Assyrian period the range had been increased to include Subat-Enlil and Ekallātum.

Requests for mobile units of artisans were usually filed by a palace intendent in writing either directly to the king or to one of his officers. For example, ARM VI: 55, a letter from Bahdi-Lim to Sunuhrahalu reads:

Mannatan has collected and sent me, as a group, artisans (mārē ummēni) who cannot go on the 「road 1 (girru). He did not send to me a mobile unit (sābam aliktam). Now then, I have sent a tablet to the king. Bring the matter to the king's attention so that he can register all the men whom he designates. Let him send to me a mobile unit, and let them bring their provision. ${ }^{4}$

But most documents in this category deal with artisans, usually acting singly, who were summoned to fill a post or to complete a task. A typical letter illustrating this situation is ARM II: 101: 8-31. Yaqqim-Addu, governor of Sagarātim, writes to Zimri-Lim:

The day on which I send this, by tablet, to my lord, 7 lengths ( $q \bar{a} n \bar{a} t$ ) of Sagarātim's wall collapsed, (namely), the bastion (šulhum) to the north of the city has fallen.

${ }^{2}$ For restorations see Falkenstein, BO, 11 (1954), 15; CAD E, 328: b, 21; and CAD $B, 124,3^{\prime}, b^{\prime}$. The translation in the last differs from the one offered above. For Situllum, see Kraus, Ein Edikt ...Ammi-saduqa, 80-81.

${ }^{3}$ Already pointed out by Bottéro, ARMT VII, $\$ 48$ (p. 229). Cf. also II: 101: 25-26.

${ }^{4}$ But cf. CAD A, 346 (sub aliktu). 


\section{Bulletin of the American Schools of Oriental Research}

In the district there is no house-builder. Dagan-ašraya [. . .] who has now been dead for quite a while. But even when he was living, the man knew nothing. When my lord commissioned me to make an ice-house (šuripum), I requested from my lord a house-builder. I was granted Ahum, the house-builder, and I have had him make the ice-house. . . . Then this man went to Mari. Now there are no housebuilders for Dür-Yahdun-Lim, Sagarātim, and the (other) two palaces. Let my lord command that a housebuilder of supe[rior abili]ty, who can repair the two walls of the two palaces, be sent to me. ${ }^{5}$

Similar appeals, couched in a variety of terms, were directed to higher authorities. They sought: animal-fatteners (V: 46: 8-10), (lock) smiths (III: 11: 34-37; XIII: 16: 11-15; 40: $13\left(\right.$ ?) ), farmers ${ }^{6}$ (I: 44: 10-20; 68: 5-12; V: 54: 5-13; XIII: 5-11), diviners (II: 15: 10-18 (?)) ${ }^{7}$ singers (I: 78; V: 73: 3'-19'; XIII: 22: 39-47), 'manual laborers' (be'ru, III: 7: 13-15), cooks (VI: 24) ${ }^{8}$ reed-mat braiders (atkuppum, XIII: 147: 27-33), lance-makers (I: 62: 16'-24') ${ }^{9}$ physicians (I: 115: 4-18; II: 127: 2-13; V: 32: 5-18; XIII: 147: 27-33), house-builders (II: 101: 8-31, 127: 2-13), leather-workers (XIII: 44: 4-15), architects (DIM . GAL, III: 47: 5-10), ${ }^{10}$ gardeners (I: 136: 10-15 (?); XIII: 40: 7-10), perfume-makers (?) (II: 136: $10-13),{ }^{11}$ riveters (XIII: $\left.16: 16-25\right),{ }^{12}$ carpenters (I: 25: 5-15; XIII: 40: 7-10), viticulturists (sämihum, XIII: 142: 37-44), millers (V: 28: 5-8), āhizu-men (II: 96: 8-17) ${ }^{13}$ and, finally scribes (I: 7: 3245).

As in the case of Ahum quoted above, a number of skilled workers managed to acquire a reputation, for our documents show them to be requested by name. Thus, for example, a letter written to Samsi-Adad was sent from Mari (I: 115: 4-18) :

Concerning Merā[num], the physician, who was to come here, I have already spoken to daddy. Now [. . . Ri[šiya] is 「about to diel. He is gravely sick. If it [plea]ses daddy, let Merānum promptly arrive here and let him cure Rišiya. Let him not die.

Again, in ARM I: 102: 9-18 Samsi-Adad writes to his son at Mari:

In truth, I should like to dispatch to you Șilli-Ea, the boat-builder. [Wri]te [to] Mari, so that they will bring to you Șilli-Ea. Then [bui]ld 60 boats in T[utt]ul.

${ }^{5}$ CAD I, $297: 2^{\prime} \mathrm{C}$. Cf. further M. Weitemeyer, Acta Orientalia, 29 (1965), 19-22; CAD $B, 56$.

${ }^{6}$ But see Birot, Syria, 41 (1964), 47.

${ }^{7}$ Falkenstein, BO, 11 (1954), 15.

${ }^{8}$ Cf. VII : $225: 7 ; 226: 47$.

'ARMT XIII, pp. 165-166 (sub 56,1.4) where sinnatum is translated 'lance' on the basis of an unpublished text. For CAD's opinion(s), see $G, 137 \mathrm{~b}$, and $\$, 201$.

It is possible to compare, however, sinnatum with Hebrew șinnā, a large shield carried by Goliath, among others.

${ }^{10}$ Warad-ilišu, the DfM.GAL of III: 47 , is called ahānu in V:28. CAD gives no specific meaning for ahānu $(A, 169)$. Should both texts be referring to the same Warad-ilišu, then ahānu could be the Akkadian equivalent to DfM.GAL. Both texts deal with construction. [Or a-ha-ni may mean "other(s)"?]

${ }^{11}$ For lurak/qûm see CAD $Z, 73-74$ (sub zarzaru). Von Soden, AHw 564, translates 'ein Schausteller??' ARM XV, 217, renders 'fakir(?), charmeur de serpents (?).'

${ }^{12}$ Here called ebbum, 'trustworthy person, experienced workman.' See CAD $E$, 4: 2'; ARMT XIII, 160 (sub 16, 1. 20). Note also the occurrence eppéšum, 'expert,' CAD $E, 245$, in XIII : 51 : 11-18. Birot, Syria, 41 (1964), 38-39 suggests a 'sorcerer' or a 'bricklayer.'

${ }^{18}$ CAD $A$, 192. AHw, 21, 'Lehrling (?).' 
Lastly, ARM V: 32, a letter written to Yasmah-Addu by Tarīm-Sakīm: Concerning Ipiq-Sin [the physician], I have once or twice said to my lord: "this man is very [able] . . . let my lord not pass him by."

Possibly because of their distinction, some artisans were permitted to choose a region in which to work. ARM XIII: 16: 11-15, is a letter from Mukannišum to Zimri-Lim:

Ibbi-Adad, the smith (URUDU.NAGAR) who is to make the sahirtum is not here. He has gone [to $\mathrm{H}$ ] anat.

For this reason, the central office sometimes seems to have lost knowledge of their whereabouts. Bahdi-Lim writes to his lord in ARM VI: 24: 11-15:

Concerning $\mathrm{Y}[\mathrm{am}]$ şi-hadnu [the cook ${ }^{14}$ ] about whom [my lord] has written to me. $\mathrm{T}$ [his man] has not come to me.

Having a reputation to preserve, some artisans often travelled widely either to study a certain herb (IV: 65: 13-18) or to collect supplies needed for their profession (II: 136: 4-13). It was probably because of such exertions that Mari acquired distinction in the field of chariotbuilding. This is clearly shown by Išme-Dagan's letter, ARM IV: 79: 5-14, sent to his brother:

Ili-gamil [a functionary at Ekallātum] is being pestered concerning the palace's chariot-making. Mari's chariots are bett[er] than those of the home-country [Assyria]. Send an apprentice cartwright ${ }^{15}$ able to manufacture chariots in the Mari fashion.

As one can expect, excellence was rewarded, sometimes bountifully. This is the case in ARM V: 73: 13-19, a letter from Ur-Samana, addressing his lord Yasmah-Addu:

Nanna-manse is available. [Because] he has learned the art of [si]nging well, I have caused him to meet with my lord. My lord has issued instructions that they give a house (to him), but they have not given (it) to him. ${ }^{16}$

Occasionally, an artisan or a functionary became so valuable that his lord was loath to permit him to travel. We thus read in ARM I: 58: 5-10, a letter from Samsi-Adad to the viceroy of Mari:

I have written five times concerning Sin-idinnam. I have waited (?) here. I have not (received) him. I will not give him the [unwanted?] post concerning which I had spoken to him.

From another tablet, ARM I: 109: 5-19, we learn that Sin-idinnam was to be appointed as circuit governor of Razamā, Burullē, and Haburātum. For this reason, Yasmah-Adad interfered:

If I send Sin-idinnam to daddy, who will be the trustworthy man who remains here and establishes the organization of this palace? ${ }^{17}$

${ }^{14}$ ARM VII : $225: 7^{\prime} ; 226: 47$, if same person.

${ }^{15}$ CAD $E, 296: 3$, eriqqu.

${ }^{16} \breve{S E S} . K I$-ma-an-sè. For the passage, cf. CAD $A$, 181:3'. CAD A, $177: 4$ b restores [tup-ša]r-ru-tam, the 'art of writing,' on the basis of the artisan's Sumerian name. If so, this is corroborated by VII : 263: ii : 7, where a Nanna-mansum is listed among other functionaries.

${ }^{17} \mathrm{CAD} I, 237-238: 2^{\prime}$. See also Etel-pi-Samaš' reply when asked to supply two reed-mat braiders to Ekallatum, ARM XIII : 139 : $7^{\prime}-9^{\prime}$. 
At times complications were encountered in the search for people qualified to fill certain posts. We gain this impression from ARM XIII: 44, a letter written to Zimri-Lim who sought an experienced leatherworker:

I have supplied an able, even an o[utstandi]ng leather-worker [writes Yasīm-Sumū]

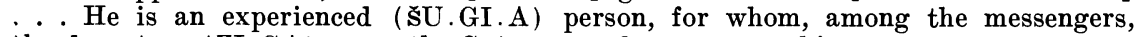
the deportees (ZI.GA), even the Suteans we kept on searching.

But once found, an artisan was not permitted long periods of idleness. This is reflected in ARM II: 2, a letter from Samsi-Adad:

1li-[Dagan (cf. V: 28: 5,7], the house-builder, why is he there? Why is he idle? the house is not even built there. . . . Send him to subat-Enlil. He will not be transferred here permanently. ${ }^{18}$ His people will remain there. As to him, he will, as before, supervise your own (team of) house-builders. Send him to subat-Enlil. At Subat-Enlil, the temple of $\mathrm{E}$ [nlil] is to be built. Let him build that temple.

If, as it seems, an employer could and did protest against indolence, we have indications that the artisans also voiced their irritation, sometimes directly to the king. Thus, in ARM V: 67: 4-15, Meqibum, a functionary, protested to Yasmah-Adad:

Concerning the plucking of sheep in Ašima, the king (Šamsi-Adad) had given the following instructions to Iškur-zikalamma: "Go, and until Meqibum comes to you, wash the sheep; then pluck them." And now (continues Meqibum), I have arrived, but there are no pluckers (here). The sheep could not be plucked. Hasidanum has sent me 150 men yesterday. Can one shear so many sheep with 150 men? Let my lord send a strong message to Hasidanum so that he will send me a unit [of workers]. Have him gather 300 to 400 men from among the Tamakumeni (?) with travel provisions enough for two days. Let my lord send (them) to me. On the third day let them pluck. ${ }^{19}$

From ARM V: 47: 5-24, one even surmises some freedom for the unhappy worker to argue his case directly at the royal palace. This is a letter to Yašmah-Addu from Išar-Lim, who seems to protest his innocence a bit too strenuously:

Concerning Idin-Sin, the carpenter, about whom my lord has written me, I have never seen that man. Since my lord has commanded me, I have not revealed the matter to anyone. I was told as follows: "He has gone to suba[t-Enli]l to denounce you." I have never written to this man, and I have never seen him. ... Let my lord write so that they bring that man to my lord. Let him not meet with the king (Samsi-Adad) in order to denounce me. ${ }^{20}$

Often artisans who were sent on missions were replaced by skilled workers of equal status. Sometimes they were exchanged for a larger number of men with lesser abilities. Examples from the former category can be found in ARM I: 99: $3^{\prime}-9^{\prime}$, and IV: 79: 16-17. For the latter type, we can point to ARM I: 44: 10-20.

${ }^{18} \mathrm{CAD} G, 38: \mathrm{b}$ (sub gamru).

${ }^{10}$ ARM II: 140 is concerned with further problems in sheep-plucking. See also CAD B, 212: 2' (sub bēru B). Cf. CAD, B, 97: 4' (sub baqāmu).

${ }^{20}$ Cf. CAD $A, 255: 6 \mathrm{~d}$. Note also ARM V: 31 which reads: "Yasmah-Dagan, the scribe, argued (?) [with ...]yasibum and left." In this case, however, an order for his arrest was issued. 
It is perhaps not out of place to direct attention to a very puzzling, yet striking divergence between the texts stemming from the Assyrian occupation and those of Zimri-Lim's era. Except for one example, ARM XIII: 41: 31-35, in itself an unclear text, all documents referring to the escape of artisans date to Assyrian times. In almost all these cases, the escapees, physicians (I: 28: 5-6; IV: 63: 5-11), woodworkers (?) (I: 63: 5-8), singers (II: 4: 4; I: 12: 5-21), ${ }^{21}$ barbers (II: 4: 5), and scribes (IV: 63: 5-10; V: 31: 5-15), seem to have headed toward the "big city," Mari. It is possible that they intended to reach Yambadian territory, where the Sumu-Epuh dynasty, hostile to Assyria, could have provided refuge. At any rate, once in Mari, the escapees were not above spending a night at a local tavern, drinking and carousing with impudence (ARM I: 28).

It is amusing to note that according to the available documents, cooks displayed high propensity for flights to freedom (I: 14; I: 28: 5-6). In addition, they were quite willing to persuade others to follow suit. In ARM I: 89, we read Šamsi-Adad's letter to his son:

The female servant Rešat-[Aya(?)] has escaped. This servant was [aided (?)] by your cook who had brought fish to me. ... If she is not found have the cook, who had brought fish to me, sent to me.

It is not impossible, of course, that more than a love for liberty impelled our cook to spread sedition.

The fate of the artisans who were unlucky enough to have been captured is not very clear. Still, ARM IV: 63, a letter from Išme-Dagan to his brother, can slightly clarify the matter:

Concerning the escapees who fled from Nurrugum (a city east of the Tigris), about whom you have written to me, send the scribe to me, and retain a physician for yourself. Keep as many as you want from among the escapees. Have their [leader (?)] brought to me. From now on, concerning the escapees who come to you, keep him who comes to you. Those you do not (intend to) keep, have them brought to me so that I can disperse them wherever is needed (cf. ARM V:61). ${ }^{21 a}$

From ARM II: 103, where artisans belonging to Sumuditana, son of Hammurapi (of Babylon?) are to be arrested by Zimri-Lim's functionary, and from the above-cited example, it is possible to conjecture that there existed an entente among the powers concerning the recovery of escaped artisans. Such an agreement is well-known from the treaties of later times. KBo V: 4: 36-40, a Hittite treaty with Hapalla, can be paraphrased as follows:

Fugitives who are free men shall not be extradited, but fugitives who are farmers, weavers, carpenters, leather-workers, or craftsmen of any kind shall be extradited. ${ }^{21 b}$

Yet, it should be noted that ARM VII: 33 and 35, texts from the Assyrian occupation, disclose that 10 shekels of ointment were released

${ }^{21}$ Both tablets deal with the same person, a singer from Ešnunna, Sin-iqišam. See below.

21a But for lines 23-24 cf. CAD $E, 328: 1,2^{\prime}$.

${ }^{21 \mathrm{~b}} \mathrm{~J}$. Friedrich, Staatsverträge (MVAG, 31), 1926, 58 ( $\$ 7$ ). A good example is to be found in IV: 5; a Turukku-man had escaped from Babylon. Following the request of its king, Samsi-Adad gives instructions for this man's arrest and deportation. 
to fugitives (munnabtī).$^{22}$ This is an amount equal to rations received by messengers and heralds (mubassirū $)$. One cannot be certain, of course, whether these fugitives were escaped artisans or important defectors from the enemy camp.

Falling into the second classification are those documents which show that large groups of artisans, skilled and semi-skilled, moved into Mari. Apparently, they were brought from nearby villages in order to fulfill their corvée duty. Occasionally, as is the case in ARM VI: 31 , a small number would be directed to a secondary palace, such as the one at Terqa. But the majority would be sent to the capital. Once in Mari, they were provided with room and board in quarters especially reserved for their use. ${ }^{23}$ Although under optimum conditions these men were to be gainfully employed at all times, there are indications that a good portion were placed on 'reserve' (DIRIG GA $=$ wattāru).$^{24}$ The number within this last group was increased by levies. This is indicated by ARM IV: 86: 32-36, a letter written to Yasmah-Adad by his brother:

As for all those (men) for whom there is no contract, and therefore cannot cultivate, you will take for yourself as replacement for the reserve. These, in truth are wattāru-reserve. Let them continuously receive wheat, oil, and wool from the palace. $^{25}$

Together with the unassigned workers (LU .DIL. DIL), and their replacements (LU EGIR), the reserves were liable to be sent out to outlying districts (ARM III: 26: 22-26) ${ }^{26}$ There, the district governors were permitted to employ them in capacities which often disregarded the workers' special talents. In addition to ARM III: 26, we possess an example in ARMT XIII: 40: 7-46 which speaks of carpenters and a smith recruited for the harvest. Another instance may be found in ARM II: 140 in which even local chieftains were drafted for sheep-plucking, a task that demanded a very large labor force (ARM V: 67; II: 140; XIII: 30).

In the third and last category we classify those itinerant artisans who chose to seek fame and fortune outside of their native lands. Citizens of Mari are known to have been engaged by Babylon (XIII: 30: 15-16; 45: 17-21), ${ }^{27}$ in Turukku territory (II: 64: 16-18) ${ }^{28}$ and possibly by Qatna (I: 46: 31-33). ARM VI: 21: 5-9 reports the return from Babylon of one of Mari's citizens, Yasim-Dagan the barber. He presumably brought back with him the latest in hair-styling and beard-curling designs.

${ }^{22}$ See also Bottéro, ARMT VII, $\$ 23$ (p. 193).

${ }^{23}$ Ibid. \& 46 (pp. 226-7).

${ }^{24}$ Cf. ARMT XIII : 30:11, and p. 56, n. 1. From II: 18: 10-13, it is clear that corvée workers sometimes escaped from Mari. In this case, replacements were provided.

${ }^{25}$ CAD $E$, 286: $5^{\prime}$.

${ }^{28} \mathrm{CAD} B$ 212: 2' sub bēru $B$.

${ }^{27}$ Text unclear in XIII : 45, but it appears that a gardener was sent to Babylon.

${ }^{28}$ Arriwaz (or Arriyuk), author of this letter, calls himself a ' son of Zimri-Lim.' He was thus perhaps a vassal. But in view of the territory's distance from Mari, it might be better to consider him Zimri-Lim's son-in-law. 
ARM I: 83 is an interesting tablet, for its shows Samsi-Adad at his wily best, responding to a request from his vassal, Aplah (a)-anda, king of Carchemish. To Yasmah-Adad, his son, he writes.

As to the narū-singer, ... give him (Aplahanda) (one) of your (own) eštalusingers. All of your eštaltu-singers are (equally) excellent; one of these eštal $\hat{u}$ singers is no less indispensable (than the other). As to the female nar $\bar{u}$-singer whom he [has requested of you], look around and [give him one who is expendable]. ${ }^{29}$

The traffic in artisans was, as can be expected, a two-way affair. We have evidence of foreign artisans working within the kingdom of Mari. From Yamhad came a carpenter who was engaged to manufacture lamassu-statues (ARM XIII: 42: 5-14). Gurruru, a barber from Ešnunna, was brought to Samsi-Adad at Talhayum (ARM II: 4: 5). As so many had done before him, he also tried, in vain, to flee from the Assyrian monarch. Another unhappy artisan was Sin-iqišam, who was a native of Ešnunna (II: 4: 4). Disenchanted with life at Mari, he started back toward his homeland. According to ARM I: 12: 5-25, he failed to reach it.

Those foreign artisans with whom Mari atmosphere agreed were apparently well-treated. A special dwelling area was set aside for them. ARM XII: 747 groups together skilled workers from Hazor, Yamhad, Carchemish, and Emar, to mention only a few. ${ }^{30}$ Choice cuts of meats, wine, oil, wheat, even ice, usually imported for royal use, were made available to them (ARMT XII: 747; XIII: 31: 6-7; 32: 6-9; 57: 4-24). ARMT XIII: 57 records the anger of Zimri-Lim upon hearing that the Babylonian contingent was badly treated (also, XIII: 123: 5-11).$^{31}$ In addition, there exists evidence to suggest that foreigners, at Mari, were sometimes permitted to conduct legal matters in accordance with their own system. ARM VIII: 67 is a text which employs non-Mesopotamian legal terminology, one which was, however, familiar to the Syrian region. In addition, all those witnessing the document were aliens. ${ }^{32}$

Despite all the brave attempts, it was nearly impossible to satisfy everyone at all times. This is reflected in ARMT XIII: 32: 5-23, a letter written to Zimri-Lim by one of his officials:

According to what my lord wrote to me, [I have prov]ided the Elamites with a jar of wine, 2 good rams, and the ice which was brought here for my lord. But as my lord [had writt]en to me thus: ... "Concerning (their) meal, concerning their gifts, they are unhappy. Either you must (examine) the problem, or some other

${ }^{29}$ CAD $E$, p. 377-378 (sub. eštal $\hat{u}$ ).

${ }^{30}$ But cf. Birot's interpretation in ARMT XII, pp. 4-5.

${ }^{31}$ We know from a text found at Tell ed-Dēr, that Sippar also established a $k \bar{a} r u m$, which probably contained artisans as well as merchants, in Mari and Mišlan. Although the text is at least half a century earlier than the era of Zimri-Lim, it is possible that the establishment prospered, at least in Mari, until the Babylonian conquest of the city. See Leemans, Foreign Trade in the Old Babylonian Period, Leyden, 1960, 106 ff., and Kupper, Syria, 51 (1964), p. 106.

${ }^{32}$ See further, Boyer, ARMT VIII, $\$ 54,222-223$, p. 98, n. 1. The non-Babylonian formula urram šeram, 'from now on,' employed in this text also occurs at Ugarit and in the Shemshāra tablet, SH 812:53-54, (J. Laessøe, The Shemshāra Tablets, 81 and 86, n. 53). For its possible Hurrian origin, see E. Weidner, AfO, 15 (194551 ), 83; Kupper, BO, 11 (1954), 119; Bottéro, $R A, 52$ (1958), p. 169. 
members of your staff must examine it for you." Having sent Yatar-Addu ${ }^{3 s}$ [to parole.

them] concerning the boat and their provision, (I know) that they are troubled neither over the gifts nor over the meals. They are troubled solely on account of the 'affair of the palace.'

This 'affair' can be clarified from ARMT: 31: 14-20. The Elamites, eager to move towards other destinations, remark:

How long shall we remain here? Why are w[e] not se[nt a]way? In addition when the [son] of our lord wen[t $t$ ] 0 Terqa, why did we not accompany the son of our lord ? ${ }^{34}$

It is hoped that the aim of this paper, to focus attention on the trade in services, has to some degree been satisfied. Although only the documents from Mari have been consulted, there is little doubt that those of other ancient Near Eastern societies, when examined, would reveal similar institutions..$^{35}$ On a wider scale, such diffusion of artisans must have helped to create an atmosphere in which foreign practices, ideas, and traditions were able to find easier acceptance.

\section{MINUTES OF THE MEETING OF THE BOARD OF TRUSTEES, MAY 3, 1968}

The regular spring meeting of the Trustees was held at the Harvard Club, 27 West 44th Street, New York, on May 3, 1968, beginning at 2:30 P. M. Present of the Trustees were: Messrs. Campbell, Colt, Crowell, Detweiler, Fowler, Hamilton, Howell, Montgomery, Phelps, Reed (for the Society of Biblical Literature and Treasurer), Reynolds, Sachs (for the American Oriental Society), Wilkinson, and Wright (President) ; of Associate Trustees: Messrs. King, Lamberg-Karlovsky, and Marks ; in other capacities: Messrs. Hansen (Second Vice-President), Grabar (Third Vice-President), Pritchard (Secretary), Newman (Administrative Director), Tucker (Evaluation Committee), Mendenhall and Williams (Jerusalem School Committee), Finkelstein (Baghdad School Committee), Sanders (Dead Sea Scroll Committee), Adams (Resident Director, Baghdad School), Schoonover (Director of Jerusalem School, 1968-69), Seiler (Accountant).

President Wright presented the agenda for the meeting, which were approved. The minutes of the December meeting of the Trustees as mailed to the Trustees were approved.

In reporting to the Trustees, the President announced that, after an affirmative telephone vote of the Executive Committee, he had retained Thomas D. Newman as

${ }^{33}$ From ARM VII : 236: $3^{\prime}$ we learn that Yatar-Addu was a merchant involved in the tin trade. His association with Elamites both here and in VI: 19:26-31 may have taught him the Elamite language and thus aided him in serving as a porte${ }^{34}$ But see Birot, Syria 41 (1964), 36-7.

${ }^{35}$ One example culled from the $\mathrm{CAD}, B, 124: 2$, is in a letter of Hammurapi (TCL 18: 155:26 ff.) :

I have brought 3 diviners, natives of Isin, to (do service at) the gate of the palace. They have given them assignments and returned them to me.

In his Le travail du metal au pays de Sumer . . . (BFPL, Université de Liège, No. 155,1960$)$, pp. 175-178, Limet wonders whether an ambulatory artisanat can be attested as early as the Ur III period. 